\title{
Clinical Variants of Allergic Rhinitis and Asthma Phenotypes in Patients with or Without a Smoking History
}

\author{
Sanja Popović-Grle \\ School of Medicine, University of Zagreb, \\ Zagreb University Hospital Center, \\ Jordanovac Lung Disease Clinic, Zagreb, \\ Croatia
}

\section{Introduction}

Asthma has been a fascinating disease for millennia, while rhinitis has been recognized only for the last two centuries. Rhinitis has been defined so late in the medical practice because of other medical priorities, such as mortal infectious diseases or wounds. Due to a larger number of doctors in the community, better education, diminished impact of epidemics, better standard and increased lifetime, medical doctors have accomplished to observe and help their patients more than previously. A significant contribution to improving allergy management has been achieved through the ability of physicians to write and publish details about their work, exchange experiences, as well as test various hypotheses and perform various experiments. Despite an enormous increase in scientific work in all parts of the world, we still do not know what asthma and rhinitis are, but in the past few decades we have learned that those conditions are closely associated.

Allergic rhinitis is one of the most common clinical presentations of allergy in human beings. It has been noticed that, during the 1990s, at the end of the past century, the prevalence of rhinitis doubled ${ }^{1}$. Allergic rhinitis is one of the 10 most common reasons for visiting general practitioners ${ }^{2}$. Allergic rhinitis is highly associated with doctor-diagnosed asthma. In an Italian study involving 18.647 subjects, a relative risk ratio (RRR) of 12.48 was obtained concerning the association between asthma and rhinitis 3 . Allergic rhinitis depends on the atopic status of the individual with an allergic reaction to a causative allergen, as well as on allergen exposure.

Asthma is defined as "a common chronic disorder of the airways that is complex and characterized by variable and recurring symptoms, airflow obstruction, bronchial hyperresponsiveness, and an underlying inflammation ${ }^{4}$.' It is estimated that 30 million people in Europe have asthma, with the economic cost of asthma amounting to $€ 17$ billion per year ${ }^{5}$. Among the asthmatic population, those who have allergic rhinitis represent different endotype of the asthma syndrome ${ }^{6}$. Distinct asthma phenotypes can be defined on the basis of the lung function, allergen sensitization, and symptoms characteristic of rhinitis and asthma. The asthma endotypes are defined on the basis of asthma phenotypes and the underlying pathophysiological mechanisms. 
Patients with asthma and allergic rhinitis phenotypes have all asthma severity degrees, from intermittent through persistent mild, moderate and severe asthma. Some of them have just an early allergic reaction in bronchial mucosa, resulting in acute bronhchospasm, with recurrent wheezing, but some have a late asthmatic response. Allergic asthma and rhinitis usually respond well to inhaled corticosteroids. They are usually not dangerous in the case of severe asthma attacks, unless the patients show risk behavior. Such risks include: noncompliance with the asthma treatment, exposure to extreme (atmospheric or toxic) conditions, and/or severe respiratory infections. They may be greatly modified depending on whether the patients are active or passive smokers. When an ill person is exposed to continuous toxic gases by his/her own will, such as smoking, the immune response in the airways alters. Acute exposure to cigarette smoke is associated with NF-kB activation and synthesis of IL-8 in the alveolar macrophages. After being translocated into the nucleus, the activated NF- $\mathrm{BB}$ binds with the DNA and regulates the expression of numerous genes involved in the inflammatory process 7 . The inflammatory cells are distributed unevenly throughout the bronchial tree, both large and small airways, and can be found both in asymptomatic smokers and in patients with chronic obstructive pulmonary diseases (COPD), whose main disease risk factor is smoking8. The only difference between the asymptomatic smokers and patients with a type of COPD was quantitative - the smokers with a COPD had a greater number of inflammatory cells, as shown in our own research 9 .

The immunological changes in the airways caused by smoking enhance the functional derangement of the airways. Smoking in adolescence reduces the lung function growth rate, so that the expected value of forced expiratory volume in the first second $\left(\mathrm{FEV}_{1}\right)^{10}$ is not attained. If adolescents gain a permanent habit of smoking, their decline in $\mathrm{FEV}_{1}$ starts much earlier than in non-smokers ${ }^{11}$. The pulmonary function is a function of age. This means that after birth the pulmonary function continues to evolve and grow, reaching its maximum in adolescence, followed by a plateau until the late twenties. Persons over 30 have a permanent annual physiological loss of lung volume and flow rate, 20-30 ml FEV 1 per year. Smokers have a greater annual decline in $\mathrm{FEV}_{1}$ than non-smokers ${ }^{12} 13,60 \mathrm{ml}$ per year ${ }^{14}$ on the average. In adolescents who smoke, the loss begins earlier than in non-smokers, significantly shortening the plateau of constant lung function in adolescence, and the process is even faster in the female population ${ }^{15}$, which is more vulnerable to cigarette smoke. A higher prevalence of asthma (OR 1.83) and rhinitis (OR 1.61) has been found in adolescent smokers than in non-smokers. It has been found that people with 1-10 pack years have an odds ratio (OR) of 1:47 for developing more severe types of asthma compared to non-smokers with allergic rhinitis, while those with over 20 pack years have a risk OR of 5:59, also compared to allergic non-smokers. Pack years represent the index of total exposure to tobacco smoke, or the overall smoking history. Pack years are important for the assessment of the risk of developing a disease. It is believed that the quantification of over 10 pack years significantly increases the risk of occurrence of a COPD, while the quantification of over 20 pack years represents a high risk of developing lung cancer and heart attack. Each medical document of a person who smokes, not just pulmonary or cardiac where it is essential, but particularly general practice documents, should contain the data on pack years. Pack years are calculated by using the following formula:

$$
\text { Pack years }=\frac{\text { Number of cigarettes per day }}{20} \times \text { years of smoking }
$$

An average person is not fully aware of the entire problem of smoking and its impact on human health. Smoking is considered to be the biggest risk factor associated with the global 
burden of disease in developed countries and amounts to $12.2 \%$, expressed in disability adjusted life years (DALY), according to the World Health Organization (WHO). Every 8 seconds someone in the world dies from smoking related diseases ${ }^{16}$. Smoking is a risk factor associated with six of the eight leading causes of death worldwide ${ }^{17}$. Smoking affects the occurrence of disease, its outcome, and in case the outcome is not death, the success of treatment also depends on whether the person is an active or former smoker. The answer to how this is possible lies in the chemical composition of tobacco smoke. Cigarette smoke has over 4000 chemical substances, 3000 respiratory irritants and about 1000 other noxious chemical substances. The International Agency for Research on Cancer has included more than 60 substances in the group of carcinogens ${ }^{18}$. To improve the effect of smoking on the palate ( $\mathrm{pH}$ changes from acidic to alkaline and increases potential addiction), tobacco leaves are combined with additives. In the United States of America (USA), these additives are regulated in the form of a list of 599 substances $^{19}$. Tobacco smoke is full of free oxygen radicals (up to the extreme number of 1017) and each radical is an unstable molecule. These radicals damage the tissue by their unpredictable and random binding with any other molecules in the vicinity, thus creating further unstable molecules, new radicals, which cause further tissue damage, up to the DNA level. Oxidants and free radicals cause sequestration and accumulation of neutrophils in the pulmonary microcirculation, as well as accumulation of macrophages in the respiratory bronchioli, with macrophages being a potential reservoir of new oxidants ${ }^{20}$.

Another important fact is that there are no less harmful cigarettes with low tar content ('light') or a safe level of smoking. European legislation prescribes limitation of the cigarette tar content to $10 \mathrm{mg}$, nicotine to $1 \mathrm{mg}$ and carbon monoxide to $10 \mathrm{mg}$ per cigarette, which has been incorporated in the Regulation on Health Safety of General Use Items since January 1, 2005 (Official Gazette 42/2004) in the Republic of Croatia. As far as the so-called light cigarettes are concerned, there is a misconception that they contain smaller quantities of harmful substances. Light cigarettes are made in the way that nicotine is overheated and carbon dioxide $\left(\mathrm{CO}_{2}\right)$ is blown into it until it assumes the form of expanding foam used to fill the same cigarette paper as ordinary tobacco. Also, light cigarettes have vent holes in the filters to assure that smoke is diluted with air during inhalation. Therefore, smokers of this type of cigarettes inhale more deeply on the average and actually receive the same amount of tar and nicotine.

There is yet another important fact that the general public is usually not aware of, and that is the influence of passive smoking on health. Passive smoking is defined as involuntary inhalation of tobacco smoke. Cigarette smoke coming from a burning cigarette tip is called second-hand smoke (SHS). The smoke remaining after putting the cigarette out is called environmental tobacco smoke (ETS). Cigarette smoke remains in the room air for the next 8 hours! ${ }^{21}$ Tobacco smoke exhaled by a smoker may be the worst of them all, because the substances in cigarette smoke change after getting in contact with human tissue enzymes. Environmental tobacco smoke (ETS) is a mixture of second-hand smoke and smoke exhaled from the lungs of smokers. Scientific evidence on passive smoking have provided nonsmokers with strong arguments in their demands to breathe clean air and prohibit smoking in indoor areas, which is now supported by legislation in most developed countries.

It is believed that passive smoking causes $10 \%$ of disease mortality in the world, in children mostly due to lower respiratory tract infections $(5,939$ million) and asthma $(651,000)$, and in adults due to ischemic heart disease (2,836 million) and also asthma (1,246 million), 
according to the 2004 data published in the Lancet based on the analysis of results from 192 countries worldwide ${ }^{22}$. It is believed that persons exposed to second-hand smoke have a higher production of immunoglobulin $\mathrm{E}(\mathrm{IgE})$, total and specific $\operatorname{IgE}$ to certain allergens ${ }^{23}$. Passive smoking has been proved to increase the risk of asthma in children. An epidemiological study of 53,879 children showed that passive smoking, either prenatal or postnatal, significantly increases the probability of asthma in children, as well as the occurrence of respiratory problems such as night time cough and wheezing24. Another large nationwide study of 102,000 children in the United States proved the connection between tobacco smoke exposure in children in their homes and prevalence of asthma, with a significance level of $p=0026^{25}$. The quality of atmospheric air or socioeconomic status of the family did not affect this correlation between asthma and household smoking. Since the prevalence of asthma increased three times in the past few decades, there are hypotheses that this increase is at least partly caused by the observed major increase in cigarette consumption in the past century ${ }^{26}$. That increase in cigarette consumption further increases the exposure to second-hand smoke, especially in children, thus also increasing the incidence of childhood asthma. It has been shown that the proportion of exhaled nitric oxide (FENO), which is used as a biomarker of airway inflammation in asthma, is associated with the exposure of children to environmental tobacco smoke at the age of 427 . Similar data found with regards to the adult population confirms that exposure to tobacco smoke in the environment increases the occurrence of asthma and its exacerbations ${ }^{28}$.

These data imply that exposure to toxic ingredients of cigarette smoke is highly associated with allergic rhinitis and/or asthma, as well as to the probability of developing asthma, especially more severe exacerbations. In this study, we were interested to find out whether smoking poses a risk on the presentation of allergic rhinitis and/or asthma, and on clinical variants of these respiratory allergy diseases in patients with diagnosed allergic rhinitis and asthma phenotypes.

\section{Methods}

The pulmonologists from the Outpatient Department of the Zagreb University Hospital Center, Jordanovac Lung Disease Clinic, located in the moderate continental climate area of Central and Eastern Europe (Zagreb, Croatia) recruited 120 adult asthma patients in consecutive order for purposes of a study carried out in the period from 2006 to 2009 in which 78 healthy persons constituted the control group, in total 198 subjects. They were considered healthy if they had no previous respiratory diseases, and if they answered negative to all questions from the Screening ECRHS II Questionnaire. The European Community Respiratory Health Survey (ECRHS) was part of the European Commission Quality of Life Programme and a nine-year prospective collaborative study carried out in 14 European countries, which collected data from more than 10000 young adults ${ }^{29}$.

All patients had had doctor-diagnosed asthma for longer than 6 months, based on a detailed interview. The symptoms that were considered asthmatic included: chronic cough, expectoration, wheezing, shortness of breath, chest tightness, exercise impairment, or night awakening. The age at asthma appearance, the number of asthma exacerbations and their severity and frequency were available; and the daily and night symptoms, exercise impairment, and dosing of rescue medication (short-acting $\beta_{2}$ agonists) were obtained. The data on sports and smoking habits were also collected. The severity of asthma was classified 
according to the Global Initiative for Asthma (GINA) into intermittent, mild persistent, moderate or severe persistent asthma ${ }^{30}$. The level of asthma control was assessed by applying the Asthma Control Test (ACT) ${ }^{31}$. The symptoms that were considered rhinitic included: sneezing, watery secretion, nasal blockage, and nasal itching ${ }^{32}$. The patients with allergic rhinitis or nasal polyps had ENT specialist-established diagnosis.

After examination, all patients performed spirometry and had to fill out a standardized questionnaire for asthmatic patients (ECRHS). Spirometry was performed at least three times from normal breathing followed by slow inhalation to a maximum, on a MasterLab Pro, version 4.3, an apparatus with a pneumotachograph. The best attempt was selected and forced expiratory volume in the first second $\left(\mathrm{FEV}_{1}\right)$ recorded according to the standard spirometric procedure (ATS/ERS) ${ }^{33}$ and then compared with the referent values according to the European Community for Coal and Steel ${ }^{34}$. The existence of an obstructive ventilatory disorder was considered if $\mathrm{FEV}_{1}$ was less than $80 \%$ of the predicted value, and the $\mathrm{FEV}_{1} / \mathrm{FVC}$ ratio under 0.7 . The bronchodilator reversibility was tested with $400 \mu \mathrm{g}$ of the short acting $\beta_{2}$-agonist (salbutamol) and considered positive if the $\mathrm{FEV}_{1}$ increased by $12 \%$ and/or $200 \mathrm{ml}$ after 15-30 minutes ${ }^{35}, 36$.

The skin prick tests (SPT) were performed on the forearm, with 15 aeroallergens manufactured by Stalallergen, France (Dermatophagoides pteronyssinus, Dermatophagoides farinae, cat dander, dog dander, moulds (Aspergillus fumigatus, Alternaria alternata, Cladosporium herbarum, Candida albicans), Latex, hazel tree pollen (Corylus avellana), birch pollen (Betulla verrucosa), grass pollen mixture (Phleum pratense, Lolium perenne, Dactylis glomerata, Festuca elatior, Poa pratensis), rye pollen (Secale cereale), short ragweed pollen (Ambrosia elatior), mugworth pollen (Artemisia vulgaris). Negative (saline solution) and positive (histamine $1 \mathrm{mg} / \mathrm{ml}$ ) controls were used. After 15 minutes, the diameter was measured in millimeters (mm), the long axis (D) and its perpendicular (d). A particular skin prick test was considered positive when the mean wheal size was greater than $3 \mathrm{~mm}$ in relation to the negative control $\{(\mathrm{D}+\mathrm{d}) / 2\} \geq 3^{37}$. The patients had not taken any antihistamines, anti-depressives or any other therapy which could influence the results of the SPT for at least a week prior to the testing. Descriptive statistics, correlation, $t$-tests and chi square tests were used for data analysis by means of standard statistical programs.

\section{Results}

From among the 198 subjects involved in this study, 120 patients had the asthmatic syndrome, 104 had allergic rhinitis and asthma, while 16 had only allergic asthma (Table 1). The duration of allergic rhinitis (AR) was significantly longer than the duration of asthma, $\mathrm{p}<0.001$ (Table 2). As far as gender is concerned, the sample of patients with allergic rhinitis and asthma consisted of significantly more female subjects (Table 3 ).

\begin{tabular}{lll}
\hline & $\mathrm{n}$ & $(\%)$ \\
\hline asthma only & 16 & $(8.1)$ \\
asthma with AR & 104 & $(52.5)$ \\
healthy & 78 & $(39.4)$ \\
total & 198 & $(100.0)$ \\
\hline
\end{tabular}

Table 1. Share of participants with asthma, allergic rhinitis and healthy participants 


\begin{tabular}{|c|c|c|c|c|c|c|c|c|}
\hline & Mean & $(\mathrm{SD})$ & Median & & (IQR) & Min & $\operatorname{Max}$ & $\begin{array}{l}\text { Shapiro- } \\
\text { Wilk Test }\end{array}$ \\
\hline \multicolumn{9}{|c|}{ Age at first onset (in years) } \\
\hline asthma & 32 & $(17.9)$ & 30 & & 7-44.5) & 1 & 70 & $\mathrm{P}=0.264$ \\
\hline allergic rhinitis & 28 & $(16.2)$ & 30 & & $(14-40)$ & 1 & 64 & $\mathrm{P}=0.122$ \\
\hline \multicolumn{9}{|c|}{ Duration of illness (in years) } \\
\hline asthma & 10 & $(10.1)$ & 5 & & $(2-19)$ & 0 & 32 & $\mathrm{P}<0.001$ \\
\hline allergic rhinitis & 13 & $(10,5)$ & 10 & & $(3-21)$ & 1 & 40 & $\mathrm{P}=0.005$ \\
\hline \multicolumn{9}{|c|}{$\begin{array}{l}\text { Abbreviation: Mean = arithmetic mean; } \mathrm{SD}=\text { standard deviation; } \mathrm{IQR}=\text { interquartile range; Shapiro } \\
\text { Wilk Test for normality of distribution }\end{array}$} \\
\hline \multicolumn{9}{|c|}{ Table 2. Asthma and allergic rhinitis descriptive parameters } \\
\hline & & \multicolumn{2}{|c|}{ Male } & \multicolumn{3}{|c|}{ Female } & \multirow{2}{*}{\multicolumn{2}{|c|}{$\mathrm{P}$}} \\
\hline & & $\mathrm{n}$ & $(\%)$ & $\mathrm{n}$ & $(\%)$ & & & \\
\hline \multicolumn{7}{|l|}{ Diagnosis } & \multicolumn{2}{|c|}{0.368} \\
\hline asthma only & & 6 & $(17.6)$ & 9 & $(11.0)$ & & & \\
\hline asthma with AR & & 28 & $(82.4)$ & 73 & $(89.0)$ & & & \\
\hline total & & 34 & (100.0) & 82 & $(100.0)$ & & & \\
\hline
\end{tabular}

Abbreviations: $\mathrm{P}$ = Fisher's Exact Test; level of statistical significance, or probability of type I (alpha)

Table 3. Prevalence of asthma and allergic rhinitis by gender

\section{Predictors of $A R$ and asthma}

\subsection{Smoking and non-smoking as Predictors of AR and asthma}

\begin{tabular}{lcccccccc}
\hline & \multicolumn{4}{c}{ Group } & \multirow{2}{*}{ total } & \multirow{2}{*}{ OR (95\%CI) } \\
\cline { 2 - 6 } & \multicolumn{2}{c}{ patients } & \multicolumn{2}{c}{ healthy } & & & \\
\cline { 2 - 6 } & $\mathrm{n}$ & $(\%)$ & $\mathrm{n}$ & $(\%)$ & $\mathrm{n}$ & $(\%)$ & \\
\hline never smoked & 14 & $(31)$ & 31 & $(69)$ & 45 & $(100)$ & 1 \\
smoked & 59 & $(56)$ & 47 & $(44)$ & 106 & $(100)$ & $2.8(1.3-5.8)$ \\
\hline
\end{tabular}

Abbreviations: $\mathrm{OR}=$ odds ratio; $95 \% \mathrm{CI}=95 \%$ confidence interval for odds ratio Fisher Exact Test, $\mathrm{P}=0.07$

Table 4. Prevalence of patients by their smoking history; base: whole sample ( $n=151)$

Ever-smoking proved to be a statistically significant predictor of developing asthma or allergic rhinitis. The prevalence of respondents with asthma or allergic rhinitis among those who had smoked at least once in their life (or still smoke) was significantly higher, 59/106 $(56 \%)$, than among the respondents who had never smoked $14 / 45(31 \%)$. The odds for being diagnosed with allergic rhinitis and asthma was 2.8 times and statistically significantly 
higher among those who had smoked or still smoke than the odds for the illness among those who had never smoked (binary logistic regression; exposed to smoke B coefficient = 1.02; standard error $=0.38$; odds ratio $=2.4895 \% \mathrm{CI}=1.3-5.8$ ). The proportion of smokers, former or current, in the whole sample of asthmatic or healthy persons was more than one half $(53.5 \%)$. In the group of active smokers, the smoking history amounted to $24.18 \pm 7.49$ pack years, while in the group of former smokers the smoking history amounted to $17.53 \pm 4.62$ pack years.

\begin{tabular}{|c|c|c|c|c|c|c|c|c|c|}
\hline \multicolumn{10}{|c|}{ Group } \\
\hline & \multicolumn{2}{|c|}{ asthma only } & \multicolumn{2}{|c|}{$\begin{array}{l}\text { allergic rhinitis } \\
\text { and asthma }\end{array}$} & \multicolumn{2}{|c|}{ healthy } & \multicolumn{2}{|c|}{ total } & \multirow[t]{2}{*}{ LR; df; P } \\
\hline & $\mathrm{n}$ & $(\%)$ & $\mathrm{n}$ & $(\%)$ & $\mathrm{n}$ & $(\%)$ & $\mathrm{n}$ & $(\%)$ & \\
\hline never smoked & 2 & (5) & 8 & (20) & 31 & (76) & 41 & (100) & $7.704 ; 2 ; 0.02$ \\
\hline smoked & 8 & (9) & 38 & $(41)$ & 47 & (51) & 93 & $(100)$ & \\
\hline
\end{tabular}

Abbreviations: $\mathrm{OR}=$ odds ratio; $95 \% \mathrm{CI}=95 \%$ confidence interval for odds ratio;

$\mathrm{LR}=$ likelihood ratio, $\mathrm{P}=$ level of statistical significance, or probability of type I (alpha)

Table 5. Prevalence of patients by their smoking history; base: whole sample ( $\mathrm{n}=134)$

The patients and healthy respondents differed statistically significantly in terms of whether they had ever smoked in life (likelihood ratio $=7.704, \mathrm{P}=0.02$ ). Among the patients who had smoked or smoke, $8 / 93(9 \%)$ had asthma, compared to $2 / 41(5 \%)$ of those who had never smoked. Also, 38/93 (41\%) of those who had smoked had asthma and allergic rhinitis, compared to $8 / 41(20 \%)$ who had never smoked.

\begin{tabular}{|c|c|c|c|c|c|c|c|}
\hline \multicolumn{8}{|c|}{ Diagnosis } \\
\hline & \multicolumn{2}{|c|}{$\begin{array}{l}\text { allergic rhinitis } \\
\text { and asthma }\end{array}$} & \multicolumn{2}{|c|}{$\begin{array}{l}\text { no respiratory } \\
\text { disease }\end{array}$} & \multicolumn{2}{|c|}{ total } & \multirow[t]{2}{*}{ OR $(95 \% \mathrm{CI})$} \\
\hline & $\mathrm{N}$ & $(\%)$ & $\mathrm{n}$ & $(\%)$ & $\mathrm{n}$ & $(\%)$ & \\
\hline never smoked & 8 & $(21)$ & 31 & (79) & 39 & (100) & 1 \\
\hline smoked & 41 & $(47)$ & 47 & (53) & 88 & (100) & $3.4(1.4-8.2)$ \\
\hline
\end{tabular}

Abbreviations: $\mathrm{OR}=$ odds ratio; $95 \% \mathrm{CI}=95 \%$ confidence interval for odds ratio Fisher Exact Test, $\mathrm{P}=0.06$

Table 6. Prevalence of allergic rhinitis and asthma by their smoking history (at least once or never); base: allergic rhinitis + asthma and healthy $(n=127)$

Ever-smoking proved to be a statistically significant predictor of allergic rhinitis and asthma. The prevalence of allergic rhinitis and asthma among the respondents who had smoked at least once in their life (or still smoke) was significantly higher, 41/88 (47\%), than among the respondents who had never smoked, $8 / 39$ (21\%). The odds for being diagnosed with allergic rhinitis and asthma was 3.4 times and statistically significantly higher among those who had smoked or still smoke than the odds for developing these illnesses among those who had never smoked (binary logistic regression; exposed to smoke B coefficient = 1.22 ; standard error $=0.45$; odds ratio $=3.4 ; 95 \% \mathrm{CI}=1.4-8.2$ ). 


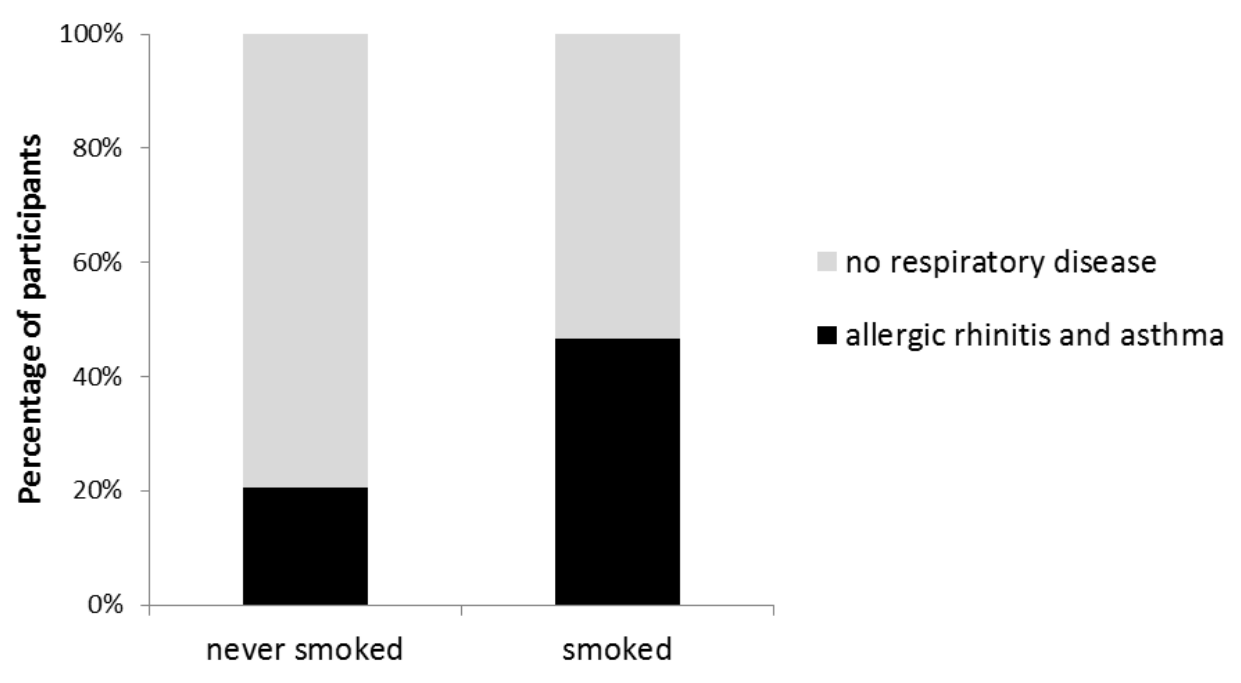

Smoking

Fig. 1. Prevalence of allergic rhinitis and asthma by smoking history (at least once or never); base: whole sample, $(n=127)$

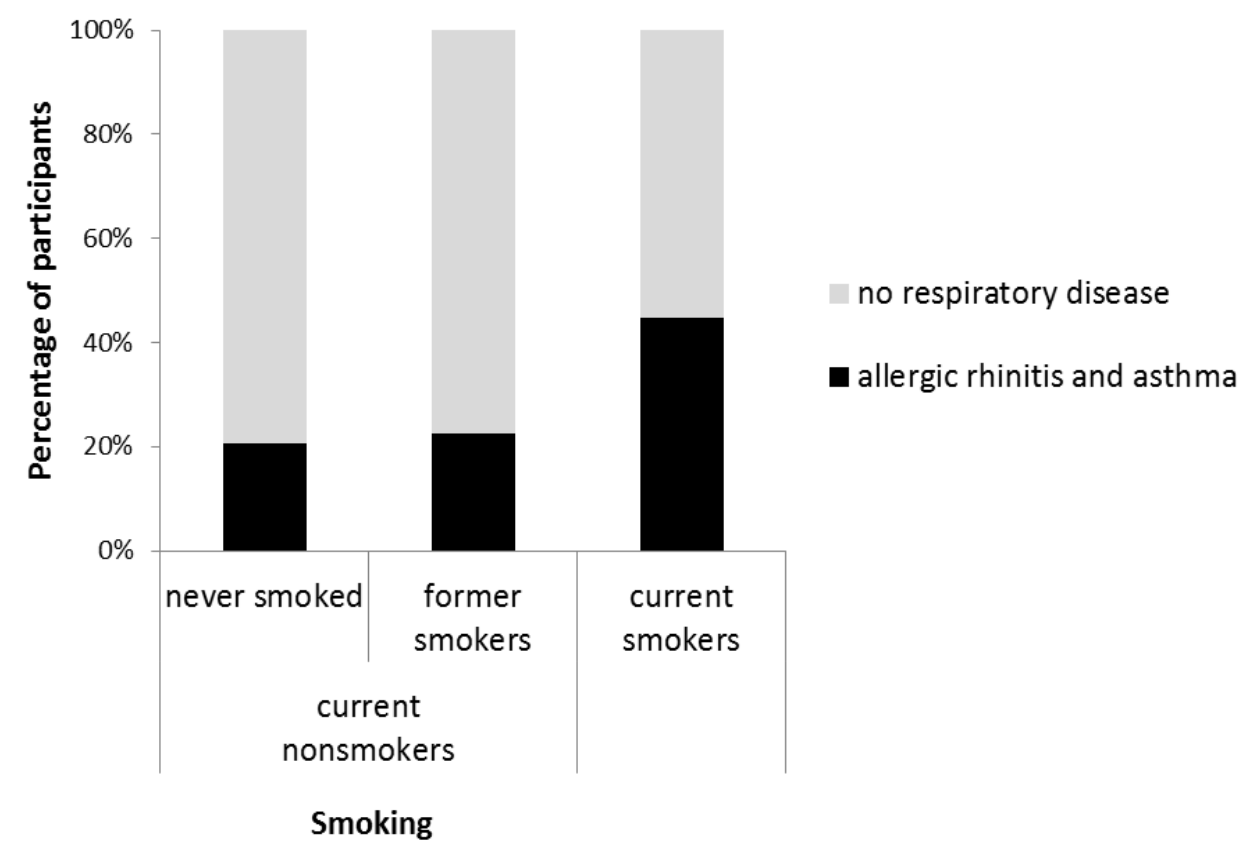

Fig. 2. Prevalence of allergic rhinitis and asthma by current non-smokers, former smokers, and non-smokers; base: whole sample, $(n=103)$ 
Current smoking proved to be a statistically significant predictor of allergic rhinitis and asthma in comparison to non-smoking. Current smoking accounted for approximately $7.3 \%$ of the variants of allergic rhinitis and asthma (Nagelkerke $R$ squared $=0.073$ ). Current smokers had a $3.1(310 \%)$ time greater chance of developing asthma and allergic rhinitis. $13 / 29(45 \%)$ current smokers had asthma and allergic rhinitis, compared to $7 / 34(21 \%)$ people who had never smoked (binary logistic regression, current smokers B coefficient = 1.14 ; standard error $=0.55$; odds ratio $=3.1,95 \% \mathrm{CI}=1.0$ to 9.5 ).

\subsection{Daily exposure to tobacco smoke and current smoking as predictors of AR and asthma}

\begin{tabular}{|c|c|c|c|}
\hline \multicolumn{2}{|c|}{ Diagnosis } & \multirow[b]{2}{*}{ total } & \multirow[b]{2}{*}{ OR $(95 \% \mathrm{CI})$} \\
\hline $\begin{array}{l}\text { allergic rhinitis } \\
\text { and asthma }\end{array}$ & $\begin{array}{c}\text { no respiratory } \\
\text { disease }\end{array}$ & & \\
\hline$(\%)$ & $(\%)$ & $(\%)$ & \\
\hline
\end{tabular}

\begin{tabular}{|c|c|c|c|c|c|c|c|}
\hline not exposed to smoke & 6 & $(14)$ & 38 & $(86)$ & 44 & $(100)$ & 1 \\
\hline exposed to smoke & 10 & (33) & 20 & (67) & 30 & $(100)$ & $3.2(1.0-10.0)$ \\
\hline smokers & 13 & $(45)$ & 16 & $(55)$ & 29 & $(100)$ & $5.2(1.7-15.9)$ \\
\hline
\end{tabular}

Abbreviations: $\mathrm{OR}=$ odds ratio $; 95 \% \mathrm{CI}=95 \%$ confidence interval for odds ratio Likelihood ratio $=9.3 ; \mathrm{df}=2 ; \mathrm{P}=0.01 ;$ contingency coefficient $=0.28$

Table 7 Prevalence of allergic rhinitis and asthma by current non-smokers' daily exposure to tobacco smoke and current smoking; base: whole sample, $(n=103)$

Both daily exposure to tobacco smoke among current non-smokers and current smoking proved to be statistically significant predictors of allergic rhinitis and asthma. The prevalence of allergic rhinitis and asthma among the current non-smokers who had been daily exposed to tobacco smoke during the period of 12 months prior to the study, was $10 / 30(33 \%)$ in comparison to the current non-smokers who had not been daily exposed to tobacco smoke, $6 / 44$ (14\%). The odds for being diagnosed with allergic rhinitis and asthma were 3.2 times and statistically significantly higher among the current non-smokers who had been daily exposed to tobacco smoke than the odds for developing these illnesses among the current non-smokers who had not been daily exposed to tobacco smoke (binary logistic regression; exposed to smoke $\mathrm{B}$ coefficient $=1.25$; standard error $=0.59$; odds ratio $=$ $3.2 ; 95 \% \mathrm{CI}=1.0-10.0)$.

The prevalence of allergic rhinitis and asthma among the current smokers, 13/29 (45\%), was about three times higher than among those who had not been daily exposed to tobacco smoke, 6/44 (14\%). The odds for developing these illnesses were 5.2 times and statistically significantly higher in the case of smokers (binary logistic regression; smokers B coefficient $=1.64$; standard error $=0.58$; odds ratio $=5.2 ; 95 \% \mathrm{CI}=1.7-15.9)$. 


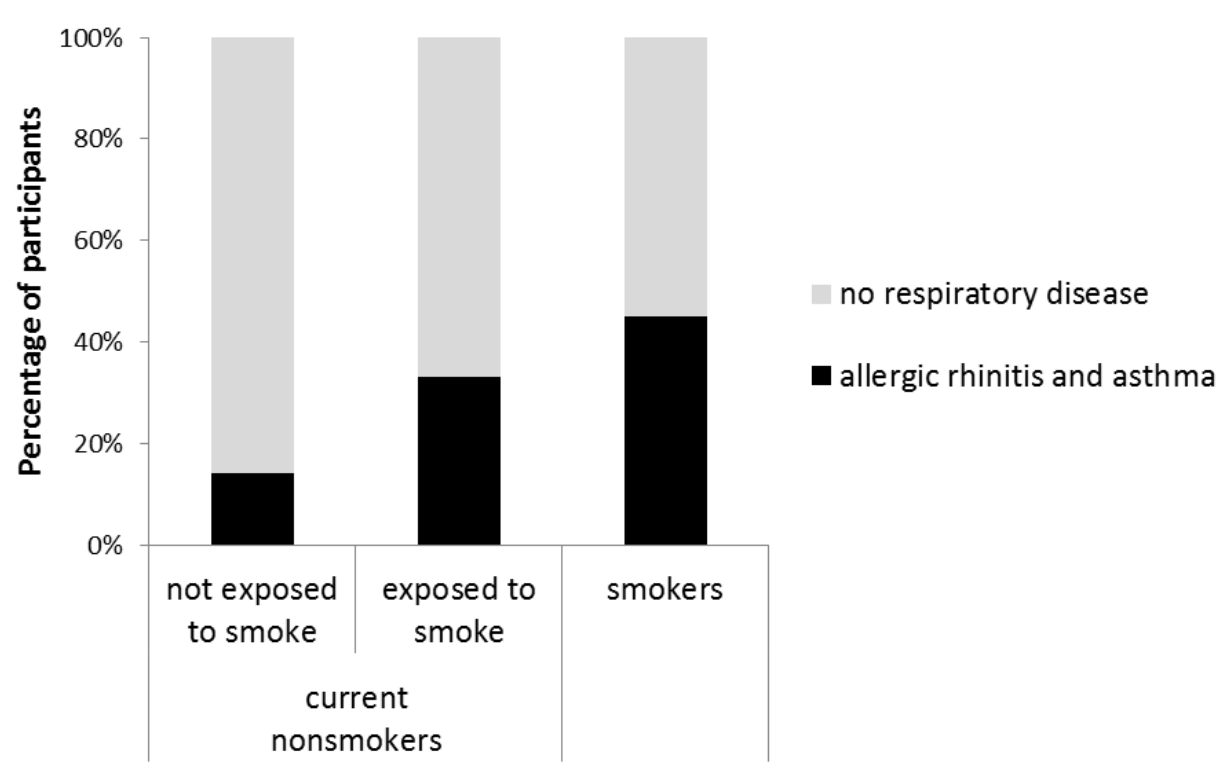

\section{Exposure to tobacco smoke}

Fig. 3. Prevalence of allergic rhinitis and asthma by current non-smokers' daily exposure to tobacco smoke and current smoking; base: whole sample, $(n=97)$

\subsection{Prevalence of patients who quit or reduced smoking}

The healthy respondents and those with allergic rhinitis and asthma did not differ significantly with regard to quitting or reducing smoking (Fisher Exact Test, $\mathrm{P}=0.249$ ). Among those with allergic rhinitis and asthma however, the difference between those who quit or reduced smoking and those who didn't was statistically significant (goodness of fit Hi square $=20.83 ; \mathrm{df}=1 ; \mathrm{P}<0.01), 88 \%$ quit or reduced smoking, while $12 \%$ of them still smoke as before.

\begin{tabular}{lccccc}
\hline & \multicolumn{5}{c}{ Diagnosis } \\
\cline { 2 - 5 } & \multicolumn{2}{c}{$\begin{array}{c}\text { allergic rhinitis } \\
\text { and asthma }\end{array}$} & $\begin{array}{c}\text { no respiratory } \\
\text { disease }\end{array}$ & P \\
\cline { 2 - 6 } & $\mathrm{n}$ & $(\%)$ & $\mathrm{n}$ & $(\%)$ & \\
\hline didn't reduce & 4 & $(12)$ & 11 & $(23)$ & 0.249 \\
reduced & 29 & $(88)$ & 36 & $(77)$ & \\
TOTAL & 33 & $(100)$ & 47 & $(100)$ & \\
\hline
\end{tabular}

Abbreviations: $\mathrm{OR}=$ odds ratio; $95 \% \mathrm{CI}=95 \%$ confidence interval for odds ratio $\mathrm{P}=$ Fisher Exact Test; level of statistical significance, or probability of type I (alpha)

Table 8. Prevalence of those who quit or reduced smoking by illness (allergic rhinitis and asthma); base: whole sample $(\mathrm{n}=70)$ 


\section{Allergy diagnostic tests (skin prick tests)}

The skin prick tests in the healthy control group were negative in the case of all tested subjects. The patients with allergic rhinitis and asthma endotypes associated with smoking were significantly more sensitized to perennial allergens, mostly to Dermatophagoides pteronyssinus $(54 \%$ of patients in the ever-smoking group and $39 \%$ in the non-smoking group). In the non-smoking group of patients with allergic rhinitis and asthma, greater sensitization was recorded to seasonal allergens, most often to grass pollen ( $31 \%$ of patients in the ever-smoking group and $42 \%$ in the non-smoking group).

\begin{tabular}{cccccc} 
& $\bar{X}$ & SD & Min. & Max. & SE \\
\hline Histamine ever-smokers & 6.25 & 1.38 & 3 & 11 & 0.21 \\
Histamine non-smokers & 7.40 & 1.57 & 4 & 12 & 0.27 \\
\hline Der $p$ ever-smokers & 5.69 & 1.75 & 3 & 9 & 0.19 \\
Der $p$ non-smokers & 5.87 & 1.83 & 3 & 14 & 0.21 \\
\hline Fel $d$ ever-smokers & 5.71 & 1.54 & 4 & 13 & 0.17 \\
Fel $d$ non-smokers & 5.92 & 1.67 & 3 & 13 & 0.16 \\
\hline Alt a ever-smokers & 4.91 & 1.22 & 3 & 8 & 0.12 \\
Alt $a$ non-smokers & 5.11 & 1.34 & 3 & 9 & 0.14 \\
\hline Bet $v$ ever-smokers & 7.63 & 1.68 & 4 & 22 & 0.31 \\
Bet $v$ non-smokers & 8.14 & 1.82 & 5 & 25 & 0.29 \\
\hline Phl $p$ ever-smokers & 6.88 & 1.91 & 5 & 18 & 0.24 \\
Phl $p$ e non-smokers & 7.49 & 1.82 & 4 & 27 & 0.28 \\
\hline Amb e ever-smokers & 7.36 & 1.65 & 5 & 19 & 0.31 \\
Amb n non-smokers & 8.10 & 1.78 & 5 & 32 & 0.34 \\
\hline
\end{tabular}

Abbreviation: $\overline{\mathrm{X}}=$ arithmetic mean; $\mathrm{SD}=$ standard deviation: Min. $=$ minimal value; Max. $=$ maximal value; $\mathrm{SE}=$ standard error; $\mathrm{mm}=$ millimeters; Der $\mathrm{p}=$ Dermatophagoides pteronyssinus; Fel $\mathrm{d}=$ Felis domestica; Alt $\mathrm{a}=$ Alternaria alternata, Bet $\mathrm{v}=$ Betula verrucosa; $\mathrm{Phl} \mathrm{p}=$ Phleum pratense; Amb e= Ambrosia elatior.

Table 9. Results of skin prick tests to common inhalation allergens in allergic rhinitis and asthma phenotypes patients with or without a smoking history, reaction by wheal size in $\mathrm{mm}$ (positive control: histamine $(1 \mathrm{mg} / \mathrm{ml})$, negative control: saline solution).

The wheal reaction to common inhalation allergens (size in $\mathrm{mm}$ ) in allergic rhinitis and asthma phenotypes patients showed a bigger diameter in patients without a smoking history than in the group of allergic ever-smoking patients (Table 17). The skin wheal reaction to pollen allergens was greater than the reaction to perennial allergens in the case of all patients.

\section{Clinical symptom variants in allergic rhinitis and asthma}

All subjects in the group of subjects with allergic rhinitis and asthma phenotypes had a few symptoms of their disease, at least three, but most subjects had more than five symptoms. The distribution of their symptoms differed whether they were current or former smokers or lifetime non-smokers. Table 18 shows less histamine-mediated symptoms of allergic rhinitis, such as sneezing or runny nose, in the medical history of non-smoking patients than in the group of smokers, however more blocked nose. 


\begin{tabular}{|ccc|}
\hline & $\begin{array}{c}\text { With a smoking history } \\
\text { (ever-smokers) } \\
n=59\end{array}$ & $\begin{array}{c}\text { Without a smoking history } \\
\text { (non-smokers) } \\
n=45\end{array}$ \\
\hline Sneezing & $28(48 \%)$ & $27(61 \%)$ \\
Runny nose & $25(43 \%)$ & $23(52 \%)$ \\
Blocked nose & $42(72 \%)$ & $24(54 \%)$ \\
Itchy nose & $12(21 \%)$ & $14(32 \%)$ \\
Itchy eyes (conjunctivitis) & $21(36 \%)$ & $12(27 \%)$
\end{tabular}

Table 10. Clinical presentation of rhinitic symptoms in patients with allergic rhinitis and asthma phenotypes with or without a smoking history

\begin{tabular}{|lcc|}
\hline Cough & $\begin{array}{c}\text { With a smoking history } \\
\text { (ever-smokers) } \\
n=68\end{array}$ & $\begin{array}{c}\text { Without a smoking history } \\
\text { (non-smokers) } \\
n=52\end{array}$ \\
Expectoration & $58(85 \%)$ & $32(61 \%)$ \\
Wheezing & $52(76 \%)$ & $15(29 \%)$ \\
Chest tightness & $27(39 \%)$ & $30(57 \%)$ \\
Shortness of breath & $13(19 \%)$ & $21(41 \%)$ \\
Exercise impairment & $22(32 \%)$ & $21(40 \%)$ \\
Night awakening & $17(25 \%)$ & $17(33 \%)$ \\
Asthma exacerbation (moderate/severe) & $14(21 \%)$ & $19(37 \%)$ \\
ACT (mean value out of exacerbation) & $21(31 \%)$ & $14(26 \%)$ \\
\hline Abbreviations: ACT Asthma Control Ter & 16 & 20 \\
\hline
\end{tabular}

Abbreviations: ACT $=$ Asthma Control Test

Table 11. Clinical presentation of asthmatic symptoms in patients with allergic rhinitis and asthma phenotypes with or without a smoking history

The respondents with the ever-smoking habit showed less chest tightness, night awakening and exercise impairment, compared to the non-smoking group, but more moderate or severe asthma exacerbations, with lower asthma control.

\begin{tabular}{lcc|}
\hline & $\begin{array}{c}\text { With a smoking history } \\
\text { (ever-smokers) } \\
n=68\end{array}$ & $\begin{array}{c}\text { Without a smoking history } \\
\text { (non-smokers) } \\
n=52\end{array}$ \\
\hline GINA I & $3(04 \%)$ & $2(05 \%)$ \\
GINA II & $18(26 \%)$ & $20(39 \%)$ \\
GINA III & $41(61 \%)$ & $26(49 \%)$ \\
GINA IV & $6(09 \%)$ & $4(07 \%)$ \\
\hline
\end{tabular}

Abbreviations: GINA= Global Initiative for Asthma

Table 12. Distribution of diagnosed patients with allergic rhinitis and asthma phenotypes according to the GINA classification, with or without a smoking history

\section{Lung fnction (FEV $)$}

The distribution of forced expiratory volume in the first second $\left(\mathrm{FEV}_{1}\right)$ level did not deviate significantly from the normal distribution among all patients (Shapiro Wilk $=0.994, \mathrm{P}=$ 
0.698), among those with asthma only (Shapiro Wilk $=0.962, \mathrm{P}=0.698$ ) or among those with asthma and allergic rhinitis (Shapiro Wilk $=0.982, \mathrm{P}=0.490$ ).

\begin{tabular}{lccccc} 
& Mean (SD) & Median (IQR) & Min & Max & $\begin{array}{c}\text { Shapiro- } \\
\text { Wilk Test }\end{array}$ \\
Whole sample & $78.7(19.87)$ & $79.4(66.3-93.3)$ & 30 & 140 & $\mathrm{P}=0.698$ \\
Asthma only & $77.1(21.11)$ & $77.2(62.9-96.7)$ & 39 & 106 & $\mathrm{P}=0.816$ \\
Asthma and allergic rhinitis & $79.9(21.56)$ & $80.8(67.3-95.8)$ & 30 & 124 & $\mathrm{P}=0.490$ \\
\hline
\end{tabular}

Abbreviation: Mean = arithmetic mean; $\mathrm{SD}$ = standard deviation; $\mathrm{IQR}=$ interquartile range; Shapiro Wilk Test for normality of distribution

Table 13. FEV1 (\% of the reference value)

\begin{tabular}{|c|c|c|c|}
\hline & \multicolumn{2}{|r|}{$\mathrm{FEV}_{1}$} & \multirow{2}{*}{$\mathrm{P}$} \\
\hline & Mean & SD & \\
\hline never smoked & $\begin{array}{r}15.22 \\
862\end{array}$ & $\begin{array}{l}4.97 \\
5.14\end{array}$ & $<0.05$ \\
\hline
\end{tabular}

Abbreviation: Mean = arithmetic mean; $\mathrm{SD}=$ standard deviation

Table 14. Difference in the FEV1 average increase (\%) after the bronchodilator test with salbutamol by current and ever-smokers, base: only ill $(n=47)$

The bronchodilator response in the smoking group was statistically significantly lower than in the non-smoking group.

Considering the skin sensitization established on the basis of skin prick tests there were more patients sensitized to perennial allergens in the smoking group (active and former smokers), most to Dermatophagoides pteronyssinus (58\%), followed by those sensitized to ragweed pollen (Ambrosia elatior) (34\%). In the non-smoking group of patients with allergic asthma, seasonal allergies were more recorded, mostly to grass pollen (42\%), while ragweed pollen and tree pollen were similarly distributed (32\% and $31 \%)$.

The exacerbation rate in both groups did not differ significantly, which may be due to the low number of study groups. Only 4/120 (3.3\%) patients were hospitalized due to asthma exacerbations during the observation period. 11/120 (9.2\%) ever-smoking patients were hospitalized for asthma exacerbations, some of them even several times. Intensive care treatment was needed in the case of 2/120 (1.7\%) patients, however no intubation or mechanical ventilation was necessary.

\section{Discussion}

Allergic rhinitis and asthma are frequent diseases posing a heavy burden for the society. Allergic rhinitis and asthma presented together are considered to be different asthma phenotype and endotype. The allergic reaction is modified depending on whether the patients are active or passive smokers. A large proportion of patients with allergic rhinitis and asthma are smokers. Our hypothesis was that there were differences in the clinical presentation of allergic rhinitis and asthma phenotypes due to exposure to tobacco smoke. In the investigated group of patients with allergic asthma, those who also had allergic rhinitis made up a significantly greater number (104/120) compared to the asthmatics 
without allergic rhinitis. The prevalence of allergic rhinitis in asthmatics in the case of our subjects was $86.7 \%$ (Table 1), involving significantly more female subjects (Table 3). Even in children from 6-12 years of age, it was found that $89.7 \%$ had moderate to severe rhinitis, which means that they have troublesome sleeping, problems with concentration and diminished learning results 38 .

From the total sample of 198 subjects, both in the case of asthmatic and healthy subjects, there were more former or current smokers (106/198) than persons who had never smoked. The proportion of ever-smokers investigated in this study $(53.5 \%)$ is greater than the proportion of ever-smokers in the general population, according to the epidemiological survey conducted on adults ${ }^{39}$ and medical students in Croatia ${ }^{40}$. The mentioned surveys showed there were $27.4 \%$ regular daily smokers over 18 , of which $34 \%$ men and $22 \%$ women.

Active smokers had a slightly higher number of pack years than former smokers, however not significantly higher. In the group of active smokers, the number of pack years amounted to $24.18 \pm 7.49$, while in the group of former smokers the number of pack years amounted to $17.53 \pm 4.62$. These data show that most smokers smoke for more than a decade or two before starting to consider quitting smoking and before they succeed to do it. Most literature data based on various studies confirm our results. Quitting smoking is a process with several phases preceding the change in behavior, which has been known for a longer period ${ }^{41}$. As smoking produces nicotine addiction, it is not easy to quit smoking due to the abstinence syndrome. Besides a strong motive, some smokers might need a nicotine replacement therapy with pharmacological agents, vareniclin or bupropion, which increases the rate of successful quitters ${ }^{42}$.

The odds for being diagnosed with allergic rhinitis and asthma in our study was 2.8 times and statistically significantly higher among those who had smoked or still smoke than the odds for developing these illnesses among those who had never smoked (Table 4). The data from other authors also show that smokers are more likely to develop asthma than nonsmokers, although smoking is not believed to cause asthma ${ }^{43}$. Tobacco smoking causes increased bronchial hyperreactivity ${ }^{44}$. After quitting smoking, bronchial hyperreactivity in asthma patients decreases in comparison to the asthma patients who continue to smoke ${ }^{45}$.

Among the patients who had smoked, 9\% had asthma, compared to 5\% of those who had never smoked. Also, $41 \%$ of those who had smoked had asthma and allergic rhinitis, compared to $20 \%$ of those who had never smoked. These results are statistically significant $(p=0.02)$, with the likelihood ratio of 7.7 for developing allergic asthma and rhinitis if smoking (Table 5).

Ever-smoking proved to be a statistically significant predictor of allergic rhinitis and asthma. The prevalence of allergic rhinitis and asthma among the respondents who had smoked at least once in their life (or still smoke) was significantly higher, $47 \%$, than among the respondents who had never smoked, 21\% (Table 6)

Daily exposure to tobacco smoke among current non-smokers and current smokers proved to be a statistically significant predictor of allergic rhinitis and asthma. There were $45 \%$ of current smokers in our group with allergic rhinitis and asthma, more than in Northern America where there were $25-35 \% 46$. The investigated current smokers, in comparison to the investigated former smokers, had a 3.1 time greater chance of developing asthma and allergic rhinitis (Figure 2). The non-smokers who had been exposed to tobacco smoke during the last 12 months prior to the study, had a 3.2 time greater chance of developing asthma and allergic rhinitis (odds ratio $=3.2 ; 95 \% \mathrm{CI}=1,0-10,0$ ) in comparison to the nonexposed non-smokers. Also in comparison to the non-exposed non-smokers, the current 
smokers, daily exposed to cigarette smoke, had a 5.2 time greater chance of developing asthma and allergic rhinitis (odds ratio $=5.2 ; 95 \% \mathrm{CI}=1.7-15.9$ ) (Table 7). Daily exposure to tobacco smoke among the former smokers did not prove to be a statistically significant predictor of allergic rhinitis and asthma (odds ratio $=0.9 ; 95 \% \mathrm{CI}=0.9-11.2$ ).

The healthy respondents and those with allergic rhinitis and asthma did not differ significantly with regards to reducing the number of cigarettes. Most subjects tried to reduce smoking ( $77 \%$ vs. $88 \%$ ) (Table 8$)$. These results are in concordance with the known fact that more than $70 \%$ of smokers want to quit smoking 47 .

The bronchodilator response in the smoking group was statistically significantly lower than in the non-smoking group, $\mathrm{p}<0.05$. $(8.62 \% \pm 5.14 v s .15 .22 \% \pm 4.97, \mathrm{p}<0.01)$ (Table 14). As it is known that smokers have higher levels of total immunoglobulin $\mathrm{E}(\operatorname{IgE})^{48}$ and a greater degree of infiltration of inflammatory cells, especially eosinophils ${ }^{49}$, in comparison to nonsmokers, it is most likely that inflammatory processes will lead to airways remodeling and fixed bronchial obstruction, with lower reversibility.

As far as skin sensitization established on the basis of skin prick tests is concerned, a greater number of patients from the smoking group (active and former smokers) were sensitized to perennial allergens, while the non-smoking patients with allergic asthma and rhinitis were more sensitized to seasonal allergens. The ever-smoking patients were most usually sensitized to Dermatophagoides pteronyssinus (54\%), while the non-smoking allergic patients were more often sensitized to grass pollen $(42 \%)$. The wheal reaction of the skin to common inhalation allergens in allergic rhinitis and asthma endotypes showed a bigger diameter in patients without a smoking history than in the group of allergic patients who had smoked at least once in their life (Table 9). It seems that smoking diminishes the histamine reaction, which is contrary to most literature data about the increased release of proinflammatory mediators ${ }^{50}$.

The distribution of the patients' symptoms differed whether they were current or former smokers or if they were lifetime non-smokers. The allergic rhinitis phenotypes included the clinical variants with nasal blockage as the most frequent symptoms in the smoking group. On the contrary, histamine mediated symptoms of allergic rhinitis, such as sneezing or runny nose, were less expressed in the group of patients with smoking in their medical history than in the group of non-smoking patients (Table 10).

These results could be influenced by different sensitization in the smoking (more to perennial allergens) and the non-smoking group (more to seasonal allergens). Another study revealed more nasal blockage in the group of patients with persistent allergic rhinitis, mainly due to house dust mite allergy ${ }^{51}$.

The asthma phenotypes included the clinical variants of more expressed chronic cough $(85 \%$ vs. $61 \%$ ) and/or expectoration ( $76 \%$ vs. $29 \%$ ) in the investigated group of smokers than in the group of non-smokers (Table 11). The asthma phenotypes could be marked by: a) baseline pulmonary function measures: b) specific allergen sensitization by SPT; c) selfreported allergies; d) symptoms characteristic of rhinitis, and e) symptoms characteristic of asthma ${ }^{52}$. The asthma phenotypes were identified as important for the genetic study of asthma and because they might have an impact on the response to asthma therapy ${ }^{53}$.

The GINA classification showed more severe degrees of asthma in the investigated group of smokers than in the group of non-smokers (Table 12), mostly in the case of moderate asthma (61\% vs. $49 \%)$. Clinically, smokers with asthma have more severe asthma symptoms than asthmatic non-smokers ${ }^{54}$.

During the past years, asthma control has become the most important part of the follow-up of asthmatic patients. The ACT has been recognized as a useful tool for asthma control and 
validated in numerous countries, including Spain ${ }^{55}$ and Croatia ${ }^{56}$. For purposes of one of our previous studies, we recruited 90 consecutive patients with asthma (18-85 years of age, of which 50 women) that filled out the Croatian version of the ACT during their regular visits to the asthma outpatient clinic and during their follow-up visit after 3 months. In the case of the patients who made the second visit (after 3 months), significant correlation between the change in the ACT score and the change in the level of asthma control according to an asthma specialist was recorded $\left(\mathrm{r}^{2}=0.437 ; P<0.001\right)$. In the current study, we found that the investigated ever-smokers had lower ACT scores in relation to the level of asthma control recorded in the investigated group of non-smokers (16 vs. 20), which means that asthma in connection with smoking entails a lower level of asthma control. Other authors also found that asthma in smokers was more difficult to control ${ }^{57}$.

The exacerbation rate in the ever-smoking group was bigger than in the non-smoking group $(31 \%$ vs. $26 \%)$. In the investigated group, $4 / 120$ (3.3\%) patients were hospitalized due to asthma exacerbation during the observation period. $11(9.2 \%)$ of them were everhospitalized for asthma exacerbation, some of them a few times. Two patients $(1.7 \%)$ were treated in the Intensive Care Unit, but neither was mechanically ventilated. According to the literature data, smokers with asthma have more frequent and severe exacerbations of asthma than non-smokers with asthma and are therefore more likely to visit hospital emergency departments, more frequently need to be placed in intensive care units, and more frequently need to be put on invasive ventilation than non-smokers, which results in higher mortality due to asthma in the case of the same ${ }^{58}$. The number of investigated patients with asthma exacerbations was not high. This result confirms the known fact that after the inhaled steroid therapy had been introduced, the number of hospitalized patients with asthma exacerbation declined dramatically.

The lung function analysis in both groups of patients with asthma, smokers and nonsmokers, even after being divided in subgroups, current and former smokers, did not show statistically significant differences (Table 13). Based on this particular study, no conclusion can be brought regarding the association of smoking and the $\mathrm{FEV}_{1}$ level, probably due to the fact that the sample included mainly young population, around 40 years of age.

According to our results, the usual course of a respiratory allergy is that allergic rhinitis precedes the appearance of asthma. The duration of allergic rhinitis (AR) was significantly longer than the duration of asthma, $\mathrm{p}<0.001$ (Table 2). Adults with allergic rhinitis who smoke are significantly more likely to develop asthma, which was confirmed by our results and other authors as well. The more a person smokes, the greater is the probability of developing more severe asthma types, thus making the asthma control more difficult ${ }^{59}$. Smoking influences the clinical presentation of allergic asthma and rhinitis, the severity of the disease and the success of the treatment. The success of the treatment is significantly better after the patient quits smoking, not just in the case of patients with asthma and allergic rhinitis, but also in lung cancer patients recording longer survival rates than those who continue to smoke. In asthmatic patients, smoking reduces the effect of drugs, such as inhaled corticosteroids 60 , which may lead to increased risk of hospitalization and intubation due to respiratory failure in the case of severe asthma exacerbations ${ }^{61}$.

Due to the fact that most patients affected with allergic rhinitis are young, at the beginning of a career, this diagnosis has such a big impact on their life comparable to the impact on the patients with moderate asthma ${ }^{62}$. Allergic rhinitis and asthma phenotyping or, even better, endotyping, is important in terms of personalized medicine, the promising way to an individualized, tailored approach to each allergic patient. 


\section{Conclusion}

Smoking causes clinical differences in patients with allergic rhinitis and asthma phenotypes. Daily exposure to tobacco smoke among the investigated current non-smokers and current smokers proved to be a statistically significant predictor of allergic rhinitis and asthma. The ever-smoking patients have more severe asthma and more moderate to severe exacerbations, but experience less symptoms. Physicians should pay more attention to patients with allergic rhinitis and asthma phenotypes who smoke.

\section{References}

[1] Ciprandi G, Vizzaccaro A, Ciprillo I, Crimi P, Canonica GW. Increase of asthma and allergic rhinitis prevalence in young Italian men. Int Arch Allergy Immunol 1996; 111:278-83.

[2] Gregory C, Cifaldi M, Tanner LA. Targeted intervention programs: creating a customized practise model to improve the treatment of allergic rhinitis in a managed care population. Am J Manage Care 1999; 5:485-96.

[3] Accordini S, Cappa V, Braggion M, Corsico AG, Bugiani M, Pirina P, Verlato G, Villani S, de Marco R, for the ISAYA Study Group. The Impact of Diagnosed and Undiagnosed Current Asthma in the General Adult Population. Int Arch Allerg Immunol 2011; 155 (4): 403-11.

[4] National Heart, Lung, and Blood Institute, National Institutes of Health, US Department of Health and Human Services. Expert panel report 3: guidelines for the diagnosis and management of asthma. Section 2, p. 1. 2007. Available at: http://www.nhlbi.nih.gov/guidelines/asthma/asthgdln.htm. Accessed June 27, 2011.

[5] European Lung Foundation and European Respiratory Society. European Lung Whitebook, 2008.

[6] Lotwall J, Cezmi AA, Bacharier LB, Bjermer L, Casale TB, Custovic A, Lemanske RF, Wardlaw AJ, Wenzel SE, Greenberger PA. Asthma endotypes: a new approach to classification of disease entities with the asthma syndrome. J Allerg Clin Immunol 2011; 127(2):355-60..

[7] Di Stefano A, Caramori G, Oates T, Capelli A, Lusuardi M, et al. Increased expression of nuclear factor- $\kappa \mathrm{B}$ in bronchial biopsies from smokers and patients with COPD. Eur Respir J 2002;20:556-63.

[8] Isajevs S, Taivans I, Svirina D, Strazda G, Kopieika U. Patterns of inflammatory responses in large and small airways in smokers with and without chronic obstructive pulmonary disease. Respration 2011; aop.10.1159/000322560.

[9] Rumora L, Milevoj L, Popović-Grle S, Barišić K, Čepelak I, Žanić Grubišić T. Level changes of blood leukocytes and intracellular signalling pathways in COPD patients with respect to the smoking attitude. Clin Biochem 2008;41(6):387-94.

[10] Gold DR, Wang X, Wypij D, Speizer FE, Ware JH, Dockery DW. Effects of cigarette smoking on lung function in adolescent boys and girls. N Engl J Med 1996;335:931937.

[11] Sherrill DL, Lebowitz MD, Knudson RJ, Burrows B. Smoking and symptom effects on the curves of lung function growth and decline. Am Rev Respir Dis 1991;144:17-22. 
[12] Fletcher C, Peto R. The natural history of chronic airflow obstruction. BMJ 1977;1:16451648.

[13] Popović-Grle S, Pavičić F, Bakran I, Plavec D. Could annual FEV1 decline in smokers predict the development of COPD? ERS Annual Congress Berlin, September 20-24, 1997. Eur Respir J 1997; 10 (suppl. 25): 94s.

[14] Anthonisen NR, Connett JE, Murray RP. Smoking and lung function of Lung Health Study participants after 11 years. Am J Respir Crit Care Med 2002;166:675-679.

[15] Downs SH, Brandli O, Zellweger JP, et al. Accelerated decline in lung function in the smoking women with airway obstruction: SAPALDIA 2 cohort study. Respir Res 2005;6:45.

[16] WHO Report on the Global Tobacco epidemic. 2008. The Mpower package.

[17] Đorđević V, Popović-Grle S. Allergic diseases and smoking. U Lipozenčić J and associates. Allergic and immune diseases. Medicinska naklada, Zagreb, 2011.

[18] International Agency for Research on Cancer. IARC Monographs on the evaluation of carcinogenic risks to humans. Volume 83: Tobacco smoke and involuntary smoking. Lyon, France, 2004.

[19] Wigand JS. Additives, cigarettes design and tobacco product regulation. A Report to the WHO, Tobacco Free Initiative, Tobacco product regulation group, Kobe, Japan 28 Jun-02 July, 2006.

[20] Nishikawa M, Nobumasa K, Ito T, Kudo M, Kaneko T et al. Superoxide mediates cigarette-smoke infiltration of neutrophils into airways through the nuclear factor- $\kappa \mathrm{B}$ activation and IL-8 mRNA expression in guinea pig in vivo. Am J Respir Cell Mol Biol 1999; 20:189-98.

[21] Šimunić M. Why (not to) smoke? 515 Questions and answers. Biblioteka časopisa "Psiha", Zagreb.

[22] Oberg M, Jaakkola MS, Woodward A, Peruga A, Pruss-Ustun A. Worlwide burden of disease from exposure to second-hand smoke: a retrospective analysis od data from 192 countries. Lancet 2011;377(9760):139-46.

[23] Kimata H. Selective induction of total and allergen-specific igE production by passive smoking. Eur J Clin Invest 2003;33811):1024-5.

[24] Pattenden S, Antova T, Neuberger M, Nikiforov B, De Sario M, et al. Parenteral smoking and children's respiratory health:independentent effects of prenatal and postnatal exposure. Tob Control 2006;15(4):294-301.

[25] Goodwin RD, Cowles RA. Household smoking and childhood asthma in the > United States: a state.level analysis. J Asthma 2008; 45(7):607-10

[26] Goodwin RD. Enviromental tobacco smoke and the epidemic of asthma in children: the role of cigarette use. Ann Allergy Asthma Immunol 2007;98(5):447-54.

[27] Perzanowski MS, Divjan A, Mellind RB, Canfield SM, Rosa MJ, Chew GL, Rundle A, Goldstein IF, Jacobson JS. Exhaled NO among inner-city children in New York City. J Asthma 2010;47(9):1015-21.

[28] Eisner MD. Environmental tobacco smoke and adult asthma. Clin Chest med 2002;23(4):749-61.

[29] (Available at: http:/ / www.ecrhs.org. accessed July 08, 2011.)

[30] Global Initiative for Asthma. Global Strategy for Asthma Management and Prevention, Global Initiative for Asthma (GINA) 2010. Available from: http:/ / www.ginasthma.org., accesed May 12, 2011. 
[31] Nathan RA, Sorkness CA, Kosinski M. Development of the Asthma Control Test: a survey for assessing asthma control. J Allerg Clin Immunol 2004;113:59-65.

[32] van Cauwenberge P, Bachert C, Passalacqua G, Bousquet J, Canonica GW, Durham SR, Fokkens WJ, Howart PH, Lund V, Malling HJ, Mygind N, Passali D, Scadding GK, Wang DY: Consensus statement on the treatment of allergic rhinitis. European Academy of Allergology and Clinical Immunology. Allergy 2000, 55(2), 116-34.

[33] Miller MR, Hankinson J, Brusasco V, Burgos F, Casaburi R, Coates A et al. Standardization of spirometry. In: ATS/ERS task forse: Standardization of lung function testing. Ed. Brusasco V, Crapo R, Viegi G. Eur Respir J 2005; 26:319-38.

[34] Report of the Working Party of the European Community for Coal and Steel: Standardization of Lung Function Tests. Bull Europ Physiopath Resp 1983, 19 (Suppl 5), 3-38.

[35] Popović-Grle S, Pavičić F, Bićanić V, Radošević Z. Kako procijeniti farmadinamski test pri opstrukciji dišnih putova? Arh hig rada toksikol 1991; 42:239-43.

[36] Tudorić N, Vrbica Ž, Pavičić F, Korolija-Marinić D, Fijačko V, Fistrić T, Gudelj I, Kukulj S, Matanić D, Miculinić N, Plavec D, Popić G, Popović-Grle S, Turkalj M: Smjernice Hrvatskog pulmološkog društva za dijagnosticiranje i liječenje astme u odraslih. Liječ Vjesn 2007, 129, 315-80.

[37] The European Academy of Allergology and Clinical immunology. Subcommitee on skin tests. Dreborg S, Frew A, ed: Allergen standardization and skin tests. Allergy 1993, 48 (Suppl 14), 48-82.

[38] Jáuregui I, Dávila I, Sastre J, Bartra J, Cuvillo A, Ferrer M, Montoro J, Mullol J, Molina X, Valero A. Validation of ARIA (Allergic Rhinitis and its Impact on Asthma) classification in a pediatric population: The PEDRIAL study.Pediatric Allergy and Immunology 2011; 22(4): 388-92.

[39] Kovačić L, Gazdek D, Samardžić S. Hrvatska zdravstvena anketa: pušenje. Acta Med Croat 2007: 61(3); 281-285.

[40] Vrazic H, Ljubicic D, Schneider NK. Tobacco use and cessation among medical students in Croatia - results of the Global Health Professionals Pilot Survey (GHPS) in Croatia, 2005.

[41] Prochaska JO, diClemente CC. Stages and processes of self-change of smoking: Toward an integrative model of change. J Consult Clin Psychol 1983;51(3):390-5.

[42] Popović-Grle S. Farmakološko liječenje prestanka pušenja. U: Popović-Grle S, Krstačić G, ur. Kako i zašto prestati pušiti? Priručnik stalnog medicinskog usavršavanja, poslijediplomski tečaj I. kategorije Medicinskog Fakulteta Sveučilišta u Zagrebu, Zagreb,2011., p.78-84.

[43] Willemse BWM, Postma DS, Timens W, ten Hacken NHT. The impact of smoking cessation on respiratory symptoms, lung function, airway hyperresponsiveness and inflammation. Eur Respir J 2004;23:464-476.

[44] Willemse BWM, Postma DS, Timens W, ten Hacken NHT. The impact of smoking cessation on respiratory symptoms, lung function, airway hyperresponsiveness and inflammation. Eur Respir J 2004;23:464-476.

[45] Thomson NC, Chaudhuri R, Livingston E. Asthma and cigarette smoking. Eur Respir J 2004;24:822-833. 
[46] Peters JM, Avol E, Navidi W, et al. A study of twelve Southern California communities with differing levels and types of air pollution: I. Prevalence of respiratory morbidity. Am J Respir Crit Care Med 1999; 159: 760-7.

[47] U.S.Centers for Disease Control. Cigarette Smoking Among Adults - United States 2000. Weekly MMWR July 26 2002. Volume 51(29) Pages 642 -645.

[48] Popović-Grle S. Criteria for allergologic diagnostics of bronchial sensitization in chronic obstructive pulmonary diseases. (Master thesis). Zagreb: Medicinski fakultet; 1989.

[49] Botelho FM, Llop-Guevara A, Trimble NJ, Nikota JK, Bauer CM, Lambert KN, Kianpour S, Jordana M, Stampfli MR. Cigarette smoke differentially impacts eosinophilia and remodeling in a house dust mite asthma model. Am J Respir Cell Mol Biol 2011. epub ahead Feb 11.

[50] Yanbaeva DG, Dentener MA, Creutzberg EC, et al. Systemic effects of smoking. Chest 2007; 131: 1557-66.

[51] Popović-Grle S, Vrbica Z, Janković M, Klarić I. Different phenotypes of intermittent and persistens respiratory allergy in Zagreb, Croatia. Ann Agric Environ Med 2009;16:137-142.

[52] Pillai SG, Tang Y, van den Oord E, Klotsman M, Barnes K et al. Factor analysis in the genetics of asthma International Network family study identifies five major quantitative asthma phenotypes. Clin Exp Allergy 2008;38(3):421-9.

[53] Gonem S, Desai D, Siddiqui S, Brightling CE. Evidence for phenotype-driven treatment in asthma patients. Curr Opin Allergy Clin Immunol 2011;11(4):381-5.

[54] Vesterinen E, Kaprio J, Koskenvuo M: Prospective study of asthma in relation to smoking habits among 14,729 adults. Thorax 1988; 43:534-539.

[55] Rodrigo GJ, Arcos JP, Nannini LJ, Neffren H, Broin MG, Contrera M, Pineyro L. Reliability and factor analysis of the Spanish version of the asthma control test. Ann Allergy Clin Immunol 2008;100(1):17-22.

[56] Popović-Grle S, Plavec D, Lampalo M, Pelicarić D, Pavičić F. Validation of the Croatian version of the asthma control test (ACT). Croat Med J 2011; in press.

[57] Stapleton N, Howard-Thompson A, George C. Hoover RM, Self Th. Smoking and asthma. J Am Board Fam Med 2011; 24(3):313-22.

[58] Silverman RA, Boudreaux ED, Woodruff PG, et al: Cigarette smoking among asthmatic adults presented to 64 emergency departments. Chest 2003; 123:1472-1479.

[59] Polosa R, Russo C, Caponnetto P, Bertino G, Sarva M, Antic T, Mancuso S, Al-Delaimy WK. Greater severity of new onset of asthma in allergic subjects who smoke: a 10year longitudinal study. Respir Res 2011;24:12(1):16 Epubahead of print 31 Jan. 2011.

[60] Thomson NC, Chaudhuri R, Livingston E. Asthma and cigarette smoking. Eur Respir J 2004;24:822-833.

[61] LeSon S, Gershwin ME. Risk factors for asthmatic patients requiring intubation: a comprehensive review. Allergologia et Immunopathologia 1995; 23:235-247.

[62] Demoly P, Didier P, Mathelier-Fusade P, Drpuet M, David M, Bonnelye G, de Blic J, Klossek JM. Physician and patient survey of allergic rhinitis in France: perceptions on prevalence, severity of symptoms, care management and specific immunotherapy. Allergy 2008; 63(8):1008-14. 


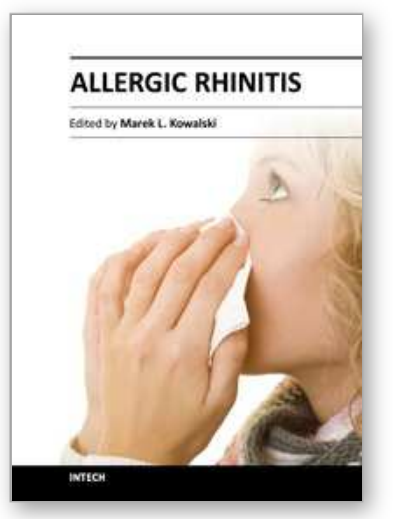

\author{
Allergic Rhinitis \\ Edited by Prof. Marek Kowalski
}

ISBN 978-953-51-0288-5

Hard cover, 214 pages

Publisher InTech

Published online 21, March, 2012

Published in print edition March, 2012

Allergic rhinitis, while troublesome for a patient, may be also a challenge for the physician. That is why physicians must still learn more on the pathophysiology, clinical spectrum and novel diagnostic and therapeutic approaches to the disease. The chapters of this volume address a variety of important topics related to allergic rhinitis. They begin with a description of innovative translational approaches allowing for unification of animal and human models. Contributing authors provide up-to-date reviews of clinical aspects of allergic rhinitis in children, its association with bronchial asthma and other co-morbid conditions. They also discuss the impact of allergic rhinitis on sleep and sports. Together with articles on diagnostic approaches as well as novel treatments, the book offers a comprehensive and stimulating review of the topic. May this book find a wide readership among allergists and other physicians interested in allergic disease, and also among pediatricians, general practitioners and other specialists who increasingly have to deal with this seemingly benign, but sometimes extremely troublesome, disease.

\title{
How to reference
}

In order to correctly reference this scholarly work, feel free to copy and paste the following:

Sanja Popović-Grle (2012). Clinical Variants of Allergic Rhinitis and Asthma Phenotypes in Patients with or Without a Smoking History, Allergic Rhinitis, Prof. Marek Kowalski (Ed.), ISBN: 978-953-51-0288-5, InTech, Available from: http://www.intechopen.com/books/allergic-rhinitis/endotypes-of-allergic-rhinitis-with-or-withoutasthma-and-smoking

\section{INTECH}

open science | open minds

\section{InTech Europe}

University Campus STeP Ri

Slavka Krautzeka 83/A

51000 Rijeka, Croatia

Phone: +385 (51) 770447

Fax: +385 (51) 686166

www.intechopen.com

\section{InTech China}

Unit 405, Office Block, Hotel Equatorial Shanghai

No.65, Yan An Road (West), Shanghai, 200040, China

中国上海市延安西路65号上海国际贵都大饭店办公楼405单元

Phone: +86-21-62489820

Fax: +86-21-62489821 
(C) 2012 The Author(s). Licensee IntechOpen. This is an open access article distributed under the terms of the Creative Commons Attribution 3.0 License, which permits unrestricted use, distribution, and reproduction in any medium, provided the original work is properly cited. 